INOBIS: Jurnal Inovasi Bisnis dan Manajemen Indonesia

Volume 04, Nomor 02, Maret 2021

Rizky Shafira Hazaroh, Yoko Tristiarto, Ardhiani Fadila

\title{
Analisis Determinan Nilai Perusahaan Pada Sektor Pertanian di Bursa Efek Indonesia
}

\author{
Rizky Shafira Hazaroh \\ Universitas Pembangunan Nasional Veteran Jakarta \\ Yoko Tristiarto \\ Universitas Pembangunan Nasional Veteran Jakarta \\ Ardhiani Fadila \\ Universitas Pembangunan Nasional Veteran Jakarta \\ * rizkyshafira@upnvj.ac.id \\ *yoko.tristiarto@upnvj.ac.id \\ *fadilaardhiani@upnvj.ac.id
}

\begin{abstract}
Abstrak
Pene1itian kuantitatif ini bertujuan untuk mengidentifikasi determinan nilai perusahaan, variabe1 yang digunakan yaitu profitabilitas diukur menggunakan Return On Equity (ROE), Kebijakan Hutang diukur dengan Debt Equity Ratio (DER), Keputusan Investasi diukur dengan Price Earning Ratio (PER), dan CSR diukur dengan Corporate Social Responsibility Disclosure 1ndex (CSRD1). Popu1asi pada penelitian ini yaitu perusahaan sektor pertanian di Bursa Efek 1ndonesia tahun 2016-2019. Dipero1eh sampe1 8 perusahaan pertanian selama 4 tahun periode penelitian. Analisis data dilakukan dengan Microsoft Exce1 2019 dan uji hipotesis dengan Ana1isis Regresi Data Pane1 menggunakan program E-Views 10.0, dengan tingkat signifikansi yaitu 5\%. Penelitian ini menunjukkan hasi1 bahwa profitabilitas, kebijakan hutang, dan keputusan investasi tidak mempengaruhi nilai perusahaan, sedangkan Corporate Social Responsibility mempengaruhi nilai perusahaan secara signifikan negatif.
\end{abstract}

Kata Kunci: profitabilitas, kebijak.an hutang, keputusan investasi, Corporate Social Responsibility, dan nilai perusahaan.

\section{Pendahuluan}

Pertanian merupakan sektor yang menempati peringkat kedua terbesar sebagai penggerak utama dalam pengembangan ekonomi di Indonesia, hal ini diungkapkan dalam portal berita Detik Finance, menunjukkan bahwa peran pertanian pada laju pertumbuhan Produk Domestik Bruto (PDB) tahun 2017 naik menjadi 13,53\%, dari sebelumnya pada tahun 2014 hanya sebesar 13,14\% terhadap ekonomi nasional. Meski begitu, survei BPS lainnya menunjukkan bahwa tingkat produktivitas pada sektor pertanian menurun secara berurutan selama tahun 2015-2017, sebesar 53,41\%, 52,36\%, dan 51,65\%. (https://www.pertanian.go.id/).

Pada bulan Mei 2020, BPS mengumumkan terjadinya penurunan sebesar 0,10\% pada Indeks Harga Perdagangan Besar (IHPB) Umum Nasional. Dimana penurunan tersebut disebabkan oleh sektor pertanian, pertambangan dan penggalian. Dimana pertanian mengalami penurunan IHPB tertinggi, yaitu $0,95 \%$. Hal tersebut disebabkan oleh pergerakan harga konsumen, bahwa beberapa harga komoditas pertanian, yaitu telur ayam ras, kelapa sawit, bawang putih, bawang bombai, cabai merah, dan beras menurun (money.kompas.com). 
Berdasarkan daftar perusahaan pada sub-sektor yang termasuk ke dalam sektor pertanian, sub-sektor perkebunan terdiri dari total perusahaan paling banyak di antara sub-sektor lainnya. Mayoritas dari sub-sektor perkebunan itu merupakan perusahaan yang memanfaatkan kelapa sawit sebagai bahan pengolahan utamanya. Dilansir dari portal berita Kompas.com, hal tersebut berhasil membuat Indonesia menjadi pengekspor sawit terbesar di dunia, dimana luas kebun sawit lndonesia telah berkebmbang pesat dalam 20 tahun terakhir, dari 2.9 juta Ha tahun 1997 menjadi 16.3 juta Ha tahun 2020.

Hal-hal tersebut dapat berpengaruh terhadap nilai perusahaan. Untuk itu, agar perusahaan mampu bersaing di tengah persaingan saat ini, setiap perusahaan tidak terkecuali pada sektor apapun harus dapat berupaya untuk meningkatkan nilai perusahaannya. Banyak indikator yang dapat diperhatikan untuk mengidentifikasi nilai perusahaan, menurut Setiono et al. (2017: 33-34), keputusan investasi dan kebijakan hutang mempengaruhi nilai perusahaan dengan sangat sensitif. Selain itu, profitabilitas juga dianggap penting karena menunjukkan hasil keuntungan yang diperoleh perusahaan melalui upaya pengelolaan dana yang diinvestasikan oleh pemegang saham (Nisasmara dan Musdholifah 2016: 118). Seiring berjalannya waktu mulai munculnya kesadaran dari sisi perusahaan untuk mengurangi dampak negatif dari operasional bisnis yang dilakukan, sehingga konsep Corporate Social Responsibility (CSR) mulai berkembang CSR dijadikan sebagai konsep akuntansi baru dengan transparansi pengungkapan kegiatan sosial yang dilaksanakan perusahaan (Nabighah 2018:2-3).

Sehingga peneliti menggunakan profitabilitas, kebijakan hutang, keputusan investasi, serta Corporate Social Responsibility sebagai indikator yang memengaruhi nilai perusahaan pada sektor pertanian.

Tabel 1. Perbandingan Rata-Rata Nilai Perusahaan, Profitabilitas, Kebijakan Hutang, Keputusan Investasi, dan CSR

\begin{tabular}{|c|c|c|c|c|c|}
\hline Tahun & $\begin{array}{c}\text { Nilai } \\
\text { Perusahaan }\end{array}$ & Profitabilitas & $\begin{array}{c}\text { Kebijakan } \\
\text { Hutang }\end{array}$ & $\begin{array}{c}\text { Keputusan } \\
\text { Investasi }\end{array}$ & CSR \\
\hline 2016 & 2.032 & 0.130 & 0.942 & 20.832 & 0.240 \\
\hline 2017 & 1.646 & 0.122 & 0.879 & 14.354 & 0.262 \\
\hline 2018 & 1.441 & 0.068 & 1.037 & 39.980 & 0.305 \\
\hline 2019 & 1.298 & 0.045 & 1.037 & 133.102 & 0.324 \\
\hline
\end{tabular}

Sumber: www.idx.co.id (data diolah)

Berdasarkan tabel di atas, adanya fluktuasi dari setiap rasio pada tahun 2016-2019. Dengan adanya fluktuasi akhirnya menimbulkan fenomena. Fenomena tersebut dapat terlihat pada tahun 2016-2017, dimana profitabilitas dan nilai perusahaan mengalami penurunan, lalu pada tahun 2017-2018 dan 2018-2019 dimana profitabilitas dan nilai perusahaan sama-sama mengalami kenaikan yang menandakan bahwa profitabilitas mempengaruhi nilai perusahaan secara positif, penelitian Sugiastuti et al. (2018), Wahyuni \& Santoso (2019), serta Nuswandari et al (2019) menyatakan mengenai profitabilitas tidak mempengaruhi nilai perusahaan, namun tabel di atas sejalan dengan penelitian Oktavia \& Desmintari (2016), Pertiwi, dkk. (2016), serta Sucipto \& Sudiyanto (2018) menje1askan bahwa nilai perusahaan dipengaruhi secara signifikan dan positif oleh profitabilitas. Fenomena lain terjadi data tahun 2016-2017 dan 2018-2019 terlihat bahwa kebijakan hutang mengalami kenaikan, sedangkan nilai perusahaan mengalami penurunan, hal itu menolak hasil penelitian Pertiwi et a1 (2016), Sugiastuti et a1 (2018), serta Febriana et al (2020), dimana kebijakan hutang tidak 
memengaruhi nilai perusahaan, namun tabel di atas sejalan dengan penelitian Ramadhan et a1 (2018) serta Ahmat \& Yuniati (2019) dimana kebijakan hutang memengaruhi nilai perusahaan secara signifikan negatif. Lalu, fenomena 1ain pada 2016-2017, keputusan investasi dan nilai perusahaan mengalami penurunan, lalu pada tahun 2017-2018 terlihat bahwa terjadinya kenaikan pada keputusan investasi dan nilai perusahaan, fenomena tersebut bertolak belakang dengan Tumiwa et a1 (2017) yang menyatakan keputusan investasi tidak mempengaruhi nilai perusahaan, namun sejalan dengan penelitian Pertiwi et al (2016), Purnama (2016), serta Nelwan \& Tulung (2018) dimana keputusan investasi memiliki pengaruh signifikan positif terhadap nilai perusahaan. Fenomena terakhir pada tahun 20162017 CSR dan nilai perusahaan sama-sama mengalami penurunan, serta tahun 2017-2018 CSR dan nilai perusahaan sama-sama mengalami kenaikan, fenomena tersebut menolak penelitian Utomo (2016) dan Wahyuni \& Santoso (2019) yang menyatakan CSR tidak memengaruhi nilai perusahaan, sedangkan Ayu \& Suarjaya (2017), Nuswandari et al (2019), Anjani \& Astika (2018) mendukung fenomena di atas, dimana CSR berpengaruh positif pada nilai perusahaan.

Dari penjelasan di atas, diambil kesimpulan bahwa nilai perusahaan dapat dipengaruhi oleh faktor-faktor seperti profitabilitas, kebijakan hutang, keputusan investasi, dan CSR. Sehingga rumusan masa1 ah pada pene1itian ini yaitu apakah profitabilitas, kebijakan hutang, keputusan investasi, dan CSR berpengaruh terhadap nilai perusahaan pada sektor pertanian di Bursa Efek Indonesia. Hasil penelitian ini nantinya diharapkan dapat menjadi bahan bacaan dan referensi pene1iti selanjutnya, serta diharapkan dapat berkontribusi mempermudah dalam pengambilan keputusan dan menentukan kebijakan bagi para investor dan manajemen perusahaan.

\section{Landasan Teori Dan Pengembangan Hipotesis}

\section{Signaling Theory}

Teori sinyal menjelaskan tentang aktivitas yang perusahaan lakukan sebagai panduan bagi investor mengenai bagaimana prospek perusahaan dilihat dari sisi manajemen. Sinya1 tersebut merupakan informasi ha1 manajemen perusahaan 1akukan da1am memenuhi hak para pemilik perusahaan. Informasi tersebut dianggap sebagai ha1 penting sehingga dapat mempengaruhi pihak luar dalam mengambil keputusan berinvestasi (Brigham dan Houston 2011: 186). Signaling theory (teori persinyalan) menyatakan bahwa suatu perusahaan akan memberi sinyal kepada para investor melalui laporan keuangan, dengan tujuan meningkatkan nilai pemegang saham. Sinyal yang diberikan berupa berbagai informasi yang berkaitan dengan upaya manajemen dalam mewujudkan kebutuhan investor, atau informasi 1ain yang mampu memperlihatkan jika perusahaan memiliki kondisi yang 1ebih baik dibanding pesaingnya. Sinyal tersebut bertujuan untuk meminimalisir adanya asimetri, dimana pihak internal mengetahui secara lebih jelas mengenai kondisi perusahaan dibanding dengan pihak luar (Fajaria 2018: 56-57).

\section{Stakeholder Theory}

Teori pemangku kepentingan adalah teori hubungan antara organisasi dan pemangku kepentingannya (Nabighah 2018: 4). Pada dasarnya stakeholder dapat terlibat untuk mengendalikan dan mempengaruhi perusahaan, salah satunya dimana hak pemegang saham terkait dengan berbagai tindakan yang ingin perusahaan 1akukan (Mariani dan Suryani 2018: 62). Stakeholder merupakan pihak yang terlibat dengan perusahaan, baik interna1 maupun 
eksterna1, di antaranya pemerintah, perusahaan pesaing, masyarakat sekitar, lingkungan internasiona1, 1embaga di 1uar perusahaan (LSM dan sejenisnya), pemerhati lingkungan, karyawan, dan 1ain sebagainya yang eksistenisnya sangat berpengaruh dan terpengaruh oleh perusahaan. Peningkatan nilai perusahaan dapat terjadi karena adanya dukungan dan kinerja stakeholder yang baik, sehingga menarik minat investor karena mereka yakin bahwa hal tersebut dapat meningkatkan kinerja perusahaan (Wahyuni dan Santoso 2019: 3).

\section{Nilai Perusahaan}

Menurut Putra \& Lestari (2016: 4044), nilai perusahaan adalah sebuah indikator kerja keuangan bagi perusahaan yang go public. Selain itu, Fuad et al. (2006: 22) mengatakan jika nilai perusahaan adalah ha1 penting untuk investor sebagai indikator evaluasi pasar secara keseluruhan. O1eh karenanya, nilai perusahaan dijelaskan sebagai harga jua1 saat perusahaan dilikuidasi.

Menurut Wiyono \& Kusuma (2017: 13) memaksima1kan nilai perusahaan berarti memperhitungkan pengaruh waktu terhadap nilai uang. Investor akan cenderung membeli saham ketika melihat perusahaan memiliki prospek baik. Akibatnya, permintaan saham yang tinggi membuat harga saham menjadi mahal karena investor memberi nilai tinggi pada perusahaan (Zuhroh 2019: 207).

\section{Profitabilitas dan Nilai Perusahaan}

Sondakh (2019: 94) menyatakan profitabilitas adalah indikator kerja manajemen dalam menge1o1a kekayaan perusahaan pada 1aba yang dihasi1kan. Menurut Nabighah (2018: 5), profitabilitas termasuk ha1 yang sangat penting untuk perusahaan, tidak cuma mempertahankan pertumbuhan bisnisnya, namun juga menguatkan keadaan keuangan perusahaan. Rasio profitabilitas yang diperiksa sejauh ini memberikan petunjuk yang berguna untuk efektivitas operasional perusahaan. Rizqia, et al (2013: 126) menyatakan bahwa ketika perusahaan mampu mempertahankan stabilitas dan menaikkan laba maka dilihat sebagai sinya1 positif bagi investor terkait kerja perusahaan.

Ha1 ini sejalan dengan pene1itian yang dilakukan Pertiwi, et a1. (2016), Ayu \& Suarjaya (2017), Mainul Q, et al (2018), Hirdinis (2019), Febriana, et a1. (2020), serta Fatimah, et a1. (2020) yang mendapatkan hasil bahwa variabel profitabilitas mempengaruhi nilai perusahaan secara signifikan, dimana ketika terjadinya kenaikan atau penurunan pada profitabilitas, maka berdampak pula pada kenaikan dan penurunan nilai perusahaan. Sehingga dapat diperoleh hipotesis bahwa profitabilitas mempengaruhi nilai perusahaan.

\section{$\mathrm{H}_{1}$ : Profitabilitas mempengaruhi nil1ai perusahaan.}

\section{Kebijakan Hutang dan Nilai Perusahaan}

Menurut Halim dalam Ramdhonah, dkk. (2019: 71), besarnya sebuah perusahaan, maka besar pula dana yang diperlukan untuk menunjang operasionalnya, sehingga ketika modal sendiri tidak mencukupi, maka sa1ah satu a1ternatif dalam mencukupi kebutuhan itu dengan menggunakan moda1 dari 1uar yaitu hutang. Menurut Tahu \& Susilo (2017: 96), semakin tinggi tingkat hutang menunjukkan nilai perusahaan akan semakin rendah, dan sebaliknya. Pemanfaatan hutang harus diperhatikan dengan sangat hati-hati oleh manajemen, dengan hutang yang besar berakibat menurunnya nilai perusahaan. Menurut Fajaria (2018: 66) hal tersebut dikarenakan perusahaan yang memiliki leverage tinggi rentan terhadap perlakuan kredit yang buruk bahkan hingga kebangkrutan. 
Ha1 ini seja1an dengan pene1itian yang dilakukan oleh Tumiwa, et a1. (2017), Aggarwal \& Padhan (2017), Mainul Q. et a1. (2018), serta Hirdinis (2019) mendapatkan hasi1 kebijakan hutang mempengaruhi nilai perusahaan, dimana artinya perubahan pada tingkat kebijakan juga mempengaruhi perubahan pada nilai perusahaan. Sehingga didapat hipotesis bahwa kebijakan hutang mempengaruhi nilai perusahaan.

\section{$\mathrm{H}_{2}$ : Kebijakan hutang mempengaruhi nilai perusahaan.}

\section{Keputusan Investasi dan Nilai Perusahaan}

Menurut Ayem \& Nugroho (2016: 7) keputusan investasi adalah tindakan penanaman modal yang dilakukan perusahaan untuk jangka waktu panjang yang mengharapkan keuntungan pada masa depan. Untuk mendapat return tinggi, tentunya terdapat risiko tinggi pula yang harus dikelola dengan baik oleh perusahaan. Menurut Sondakh (2019: 1) dengan peluang investasi maka memberikan tanda yang positif mengenai masa depan pertumbuhan perusahaan, sehingga menaikkan harga saham dan nilai perusahaan ikut naik. Cahyono \& Sulistyawati (2016: 50) membuktikan bahwa nilai perusahaan dapat berdampak positif dari keputusan investasi. Hasil penelitian yang didapat yaitu kesanggupan perusahaan untuk memaksima1kan investasi untuk upaya menghasi1kan keuntungan sesuai jum1ah dana. Hal tersebut mendukung teori sinyal, dimana tindakan investasi memberikan tanda yang baik terhadap kinerja perusahaan pada masa depan, kemudian kenaikan harga saham digunakan sebagai indikator nilai perusahaan.

Pene1itian yang dilakukan oleh Pertiwi et al. (2016) dan Purnama (2016) seja1an dengan hal tersebut, dimana mendapatkan hasil bahwa keputusan investasi mempengaruhi nilai perusahaan secara signifikan, dimana kenaikan atau penurunan yang terjadi pada keputusan investasi juga berdampak pada kenaikan atau penurunan niIai perusahaan. Sehingga dapat diperoleh hipotesis bahwa keputusan investasi mempengaruhi ni1ai perusahaan.

\section{$\mathrm{H}_{3}$ : Keputusan investasi mempengaruhi ni1ai perusahaan.}

\section{Corporate Social Responsibility dan Nilai Perusahaan}

Corporate Social Responsibility (CSR) adalah tindakan perusahaan dalam mewujudkan tanggung jawab sosia1 dan lingkungan. Dari tindakan tersebut akan memberikan pengaruh terhadap masyarakat untuk menentukan keputusan dalam berinvestasi di perusahaan. Dimana nilai perusahaan akan meningkat seiring dengan semakin banyaknya informasi yang diungkapkan terkait tanggung jawab perusahaan terhadap sosial. Karena dapat mengubah cara pandang masyarakat terhadap perusahaan, dimana menganggap bahwa perusahaan tidak sekedar mengincar keuntungan saja, tapi juga kontribusinya terhadap lingkungan masyarakat atau pihak eksternal perusahaan (Susila \& Prena 2019: 82).

CSR merupakan penerapan konsep triple bottom line. Istilah ini diciptakan untuk menggambarkan nilai ekonomi, lingkungan, dan sosial dari investasi yang mungkin bertambah di 1uar garis bawah keuangan perusahaan (Hammer \& Pivo 2016: 1).

Menurut Acep et a1 (2019: 214), prinsip triple bottom line ditabulasikan sebagai berikut: 
INOBIS: Jurnal Inovasi Bisnis dan Manajemen Indonesia

Volume 04, Nomor 02, Maret 2021

Rizky Shafira Hazaroh, Yoko Tristiarto, Ardhiani Fadila

Tabel 2. Prinsip Triple Bottom Line pada CSR

\begin{tabular}{|c|c|c|}
\hline No & $\begin{array}{c}\text { Konsep Triple Bottom } \\
\text { Line pada CSR }\end{array}$ & Indikator pengukuran \\
\hline 1 & Profit (Keuntungan) & $\begin{array}{l}\text { Keuntungan menjadi tujuan bisnis } \\
\text { Keuntungan sebagai pendorong untuk bekerja secara lebih } \\
\text { efisien } \\
\text { Keuntungan dicapai dengan ukuran perbandingan standar } \\
\text { dengan bisnis lainnya } \\
\text { Keuntungan sebagai objek pajak }\end{array}$ \\
\hline 2 & People (Sosial) & $\begin{array}{l}\text { Peduli terhadap kesejahteraan masyarakat } \\
\text { Kesadaran dimana perusahaan hidup di tengah masyarakat } \\
\text { Perusahaan harus dekat dengan masyarakat } \\
\text { Komunitas adalah sumber kehidupan perusahaan }\end{array}$ \\
\hline 3 & $\begin{array}{l}\text { Planet (Menjaga } \\
\text { konservasi alam) }\end{array}$ & $\begin{array}{l}\text { Perusahaan peduli terhadap lingkungan } \\
\text { Perusahaan peduli terhadap konservasi keanekaragaman } \\
\text { hayati } \\
\text { Perusahaan sadar akan kebutuhan sumber daya alam } \\
\text { Perusahaan sadar bahwa hal yang dilakukan tidak akan } \\
\text { merusak alam }\end{array}$ \\
\hline
\end{tabular}

Sumber: Jurnal Acep et al (2019)

Teori stakeholder mengungkapkan dimana perusahaan tidak hanya menjalankan kegiatan operaasional demi kepentingan sendiri, namun harus dapat memberi manfaat untuk pihak stakeholder. Hubungan antara CSR, kinerja perusahaan dan nilai perusahaan tidak terlepas dari adanya dukungan dari stakeholder (Akisik \& Gal 2017: 35-36). Dampak nilai kegiatan CSR sangat mempengaruhi posisi perusahaan secara khusus. Perusahaan yang membedakan diri mereka sendiri dengan menerapkan CSR, mengalami peningkatan nilai perusahaan dibandingkan dengan perusahaan pesaing yang tidak menerapkannya (Ogachi \& Zoltan 2020: $10)$.

Ha1 tersebut seja1an dengan penelitian yang dilakukan oleh Ayu \& Suarjaya (2017) dan Nuswandari, et al (2019) menunjukkan hasil bahwa CSR mempengaruhi nilai perusahaan, dimana kenaikan atau penurunan pada pengungkapan CSR juga berdampak pada kenaikan atau penurunan nilai perusahaan. Sehingga dapat diperoleh hipotesis bahwa CSR mempengaruhi nilai perusahaan.

\section{$\mathrm{H}_{4}$ : Corporate Socia1 Responsibility (CSR) mempengaruhi nilai perusahaan.}

\section{Metode Penelitian \\ Definisi Operasional \\ Variabel Dependen}

Variabel dependen (Y) yang digunakan da1am pene1itian ini ada1ah nilai perusahaan yaitu nilai yang mengindikasi kemampuan perusahaan untuk mensejahterakan para pemiliknya, diukur berdasarkan Price Book Value (PBV), dimana semakin besar nilai rasio ini maka artinya pasar semakin yakin akan harapannya terhadap perusahaan tersebut. Dengan rumus sebagai berikut:

$$
\text { Price Book Value }(P B V)=\frac{\text { Harga per 1embar saham }}{\text { Ni1ai buku per 1embar saham }}
$$

\section{Variabel Independen}

Variabe1 indepnden da1am penelitian ini, di antaranya: 
a. Profitabilitas $\left(\mathrm{X}_{1}\right)$

Profitabilitas ada1ah kesanggupan perusahaan untuk mengelola sumber daya yang dimilikinya dalam mendapatkan pendapatan yang melebihi biaya awalnya atau biasa disebut dengan laba. Pada penelitian ini diukur menggunakan Return On Equity (ROE), dengan rumus sebagai berikut:

$$
\text { Return On Equity }(R O E)=\frac{\text { Laba Bersih }}{\text { Modal Saham }}
$$

b. Kebijakan Hutang $\left(\mathrm{X}_{2}\right)$

Kebijakan hutang yaitu tindakan pihak manajemen dalam mendapatkan dana dari luar perusahaan guna membiayai aktivitas operasional perusahaan. Pada pene1itian ini diukur menggunakan Debt Equity Ratio (DER), dengan rumus sebagai berikut:

$$
\text { Debt Equity Ratio }(D E R)=\frac{\text { Total Hutang }}{\text { Modal Sendiri }}
$$

c. Keputusan Investasi $\left(\mathrm{X}_{3}\right)$

Keputusan investasi ada1ah tindakan dalam mengalokasikan dana perusahaan pada suatu investasi yang diharapkan akan menghasilkan keuntungan pada masa depan. Pada penelitian ini diukur menggunakan Price Earning Ratio (PER), dengan rumus sebagai berikut:

$$
\text { Price Earning Ratio }=\frac{\text { Harga Saham per Lembar }}{\text { Laba per Lembar }}
$$

d. Corporate Social Responsibility $\left(\mathrm{X}_{4}\right)$

Corporate Social Responsibility (CSR) adalah aktivitas dilakukan perusahaan sebagai tanggung jawab dalam bentuk sosial serta terhadap lingkungan tempat perusahaan berada. Pada penelitian ini diukur menggunakan Corporate Soc iaI Responsibility Disclosure lndex (CSRDl) berdasarkan GIobaI Reporting lnitiative (GRl) G4, dimana terdiri dari 91 indikator. Perhitungan indeks CSR menggunakan variabel dummy, yaitu setiap item yang diungkapkan oleh perusahaan bernilai 1 namun jika tidak diungkapkan berni1ai 0 (Wahyuni \& Santoso, 2019, hlm.6). Berikut rumusnya:

$$
\text { Corporate Social Responsibility Disclosure Index }=\frac{\sum X j}{\mathrm{Nj}}
$$

Keterangan:

$\mathrm{Xj}$ = item pengungkapan perusahaan (diberi nilai 1 jika item diungkapkan, nilai 0 jika tidak diungkapkan)

$\mathrm{Nj}=$ jum1ah item yang disarankan; $\mathrm{nj}=91$

\section{Populasi dan Sampel}

Populasi pada pene1itian ini ada1ah perusahaan sektor pertanian di Bursa Efek lndonesia selama periode 2016-2019.

Teknik penentuan sampel pada penelitian ini dengan metode purposive sampling dimana penentuan sampe1 berdasarkan kriteria khusus sehingga 1ayak untuk dijadikan sebagai sampe1 (Noor 2017: 155). Penelitian ini menggunakan sampel perusahaan sektor pertanian yang terdaftar pada Bursa Efek lndonesia se1ama 2016-2019 dengan kriteria sebagai berikut:

a. Perusahaan sektor pertanian di Bursa Efek lndonesia selama periode 2016-2019. 
b. Perusahaan yang mempublikasikan 1aporan keuangan tahunan dalam mata uang Rupiah dan telah diaudit secara konsisten selama 2016-2019.

c. Perusahaan yang memperoleh laba selama periode penelitian.

Sampe1 penelitian yaitu perusahaan pertanian di Bursa Efek Indonesia (BEI) yang sesuai dengan kriteria sampe 1 adalah sebanyak 8 perusahaan.

\section{Teknik Pengumpulan Data}

Penelitian ini memanfaatkan data jenis sekunder, yaitu data didapat dari pihak ketiga. Da1am penelitian ini, data sekundernya ada1ah 1aporan keuangan dan 1aporan tahunan perusahaan sektor pertanian dipublikasikan di Bursa Efek Indonesia selama tahun 2016-2019.

\section{Teknik Analisis}

Teknik analisis data pada pene1itian ini dibantu dengan aplikasi Microsoft Excel 2019, E-views 10.0, dan juga menggunakan metode analisis regresi data pane1.

\section{Statistik Deskriptif}

Sugiyono (2017: 147) menyatakan statistik deskriptif merupakan teknik analisis data dimana menggambarkan data yang terkumpu1 sesuai apa adanya tidak bermaksud menyimpulkan yang berlaku untuk umum atau generalisasi. Pada penelitian ini, data yang digunakan adalah Ni1ai Perusahaan (PBV), Profitabilitas (ROE), Kebijakan Hutang (DER), Keputusan Investasi (PER), Corporate Social Responsibility (CSRDI) pada perusahaan pertanian.

\section{Model Regresi Data Panel}

Ajij a (20 11: 25) menyatakan data panel adalah kombinasi dari time series dan cross section. Time series yaitu data dari waktu ke waktu pada satu objek. Sedangkan cross section adalah data dari beberapa objek pada tahun yang sama atau data dalam satu waktu pada beberapa objek. Bentuk umum regresi data pane1 ada1ah sebagai berikut:

Dimana:

$$
Y_{\text {it }}=\beta_{0}+\beta_{1} X_{1}+\beta_{2} X_{2}+\beta_{3} X_{3}+\beta_{4} X_{4}+\mu_{i t}
$$

$$
\begin{array}{ll}
\mathrm{Y}_{\mathrm{it}} & =\text { Nilai Perusahaan } \\
\mathrm{X}_{1} & =\text { Profitabilitas } \\
\mathrm{X}_{2} & =\text { Kebijakan Hutang } \\
\mathrm{X}_{3} & =\text { Keputusan lnvestasi } \\
\mathrm{X}_{4} & =\text { Corporate Social Responsibility (CSR) } \\
\beta & =\text { Konstanta } \\
\mathrm{i} & =\text { Nama Perusahaan Pertanian } \\
\mathrm{t} & =\text { Periode Waktu } \\
\mu & =\text { Error Term }
\end{array}
$$

\section{Hasil Dan Pembahasan Statistik Deskriptif}

Berdasarkan hasi1 pengolahan data dengan memanfaatkan aplikasi E-Views 10.0, diperoleh hasi1 sebagai berikut: 
Tabel 3. Hasil Statistik Deskriptif

\begin{tabular}{|l|c|c|c|c|c|}
\hline & PBV & ROE & DER & PER & CSRDI \\
\hline Mean & 1.599813 & 0.091250 & 0.973750 & 52.06666 & 0.283250 \\
\hline Median & 1.266500 & 0.080000 & 1.071500 & 18.81200 & 0.291500 \\
\hline Maximum & 3.861000 & 0.255000 & 2.208000 & 686.9920 & 0.429000 \\
\hline Minimum & 0.870000 & 0.003000 & 0.171000 & 3.775000 & 0.143000 \\
\hline Std. Dev. & 0.769634 & 0.064163 & 0.637329 & 121.4357 & 0.070240 \\
\hline & & & & & \\
\hline Observations & 32 & 32 & 32 & 32 & 32 \\
\hline
\end{tabular}

Sumber: data diolah dari E-views

\section{Analisis Regresi Data Panel}

Untuk menentukan model yang terbaik dalam metode analisis regresi data pane1, maka pengujian dilakukan dengan 3 cara, yaitu uji F Restricted, uji Haussman, dan uji Lagrange Multiplier.

\section{Uji F Restricted (Pooled Least Square vs Fixed Effect Mode1)}

Tabel 4. Hasil Uji F Restricted

Redundant Fixed Effects Tests

Equation: Untitled

Test cross-section fixed effects

\begin{tabular}{lcrc}
\hline \hline Effects Test & Statistic & d.f. & Prob. \\
\hline \hline Cross-section F & 12.236351 & $(7,20)$ & 0.0000 \\
Cross-section Chi-square & 53.262133 & 7 & 0.0000 \\
\hline \hline
\end{tabular}

Sumber: data diolah dari E-views

Dari tabe1 4, diketahui nilai probabilitas Cross Section Chi-Square da1am pene1itian ini sebesar $0.0000<0.05$, maka $\mathrm{H}_{0}$ ditolak dan $\mathrm{H}_{1}$ diterima, sehingga mode 1 yang paling cocok digunakan adalah Fixed Effect Model.

2. Uji Hausman (Random Effect Mode1 vs Fixed Effect Mode1)

Tabel 5. Hasil Uji Haussman

Correlated Random Effects - Hausman Test

Equation: Untitled

Test cross-section random effects

Chi-Sq.

Test Summary Statistic Chi-Sq. d.f. Prob.

$\begin{array}{llll}\text { Cross-section random } & 50.980676 & 4 & 0.0000\end{array}$

Sumber: data diolah dari E-views 
Melalui tabel 12, maka nilai probabilitas Cross Section Random dalam penelitian ini yaitu $0.0000<0.05$, maka $\mathrm{H}_{0}$ ditolak dan $\mathrm{H}_{1}$ diterima, sehingga mode1 yang paling cocok adalah Fixed Effect Model.

Berdasarkan hasil dari uji F Restricted dan uji Haussman yang telah dilakukan, maka dapat disimpulkan bahwa mode1 yang akan digunakan da1am penelitian ini ada1ah Fixed Effect Mode1, karena uji F Restricted dan uji Haussman mendapatkan hasil yang sama yaitu Fixed Effect ModeI. Sehingga tidak perlu lagi dilakukan uji Lagrange MuItipIier. Berikut ini merupakan pengaruh variabe1 independen terhadap variabe1 dependen me1a1ui hasil estimasi analisis.

Tabel 6. Hasil Model Regresi Data Panel

Dependent Variable: Nilai Perusahaan

(PBV)

Method: Panel Least Squares

Date: 01/25/21 Time: 09:19

Sample: 20162019

Periods included: 4

Cross-sections included: 8

Total panel (balanced) observations: 32

\begin{tabular}{crrrr}
\hline \hline Variable & Coefficient & Std. Error & t-Statistic & Prob. \\
\hline \hline C & 3.834990 & 0.792448 & 4.839422 & 0.0001 \\
ROE & -1.737226 & 1.659507 & -1.046833 & 0.3077 \\
DER & -0.149907 & 0.464822 & -0.322503 & 0.7504 \\
PER & -0.001142 & 0.000758 & -1.505875 & 0.1477 \\
CSRDI & -6.606304 & 2.125364 & -3.108317 & 0.0055 \\
\hline
\end{tabular}

Sumber: data diolah dari E-views

Melalui tabe1 13, dapat dilihat hasil olah data menggunakan model regresi data pane1 mela1ui program E-Views 10.0, sehingga persamaan regresi dirumuskan seperti berikut ini:

PBV $=3.834990-1.737226 \mathrm{ROE}-0.149907 \mathrm{DER}-0.001142 \mathrm{PER}-6.606304 \mathrm{CSRDI}$

\section{Uji Parsial (Uji t)}

Tabel 7. Hasil Uji t

\begin{tabular}{ccc}
\hline \hline Variable & t-Statistic & Prob. \\
\hline \hline C & 4.839422 & 0.0001 \\
ROE & -1.046833 & 0.3077 \\
DER & -0.322503 & 0.7504 \\
PER & -1.505875 & 0.1477 \\
CSRDI & -3.108317 & 0.0055 \\
\hline \hline
\end{tabular}

Sumber: data diolah dari E-views 
Dari tabe 1 7, hasi1 olah data statistik memanfaatkan program E-Views Version 10, teridentifikasi bahwa pengaruh variabe1 independen akan variabe1 dependen secara parsia1 ada1ah sebagai berikut:

1. Pengaruh Profitabilitas terhadap Ni1ai Perusahaan

Memper1ihatkan tingkat signifikansi sejum1ah $0.3077>0.05$ dan koefisien -1.737226 serta $\mathrm{t}_{\text {hitung }}<\mathrm{t}_{\text {tabel }}$ yaitu $1.046833<2.05183$, sehingga menerima $\mathrm{H}_{0}$ dan menolak $\mathrm{H}_{\mathrm{a}}$, maka profitabilitas tidak mempengaruhi nilai perusahaan.

2. Pengaruh Kebijakan Hutang terhadap Ni1ai Perusahaan

Menunjukkan tingkat signifikansi $0.7504>0.05$ dan koefisien -0.149907 serta memiliki nilai $\mathrm{t}_{\text {hitung }}<\mathrm{t}_{\text {tabel }}$ yaitu $0.322503<2.05183$, sehingga menerima $\mathrm{H}_{0}$ dan menolak $\mathrm{H}_{\mathrm{a}}$, maka kebijakan hutang tidak mempengaruhi nilai perusahaan.

3. Pengaruh Keputusan lnvestasi terhadap Nilai Perusahaan

Memiliki tingkat signifikansi $0.1477>0.05$ dan koefisien -0.001142 serta memiliki thitung $<\mathrm{t}_{\text {tabel }}$ yaitu $1.505875<2.05183$, sehingga menerima $\mathrm{H}_{0}$ dan menolak $\mathrm{H}_{\mathrm{a}}$, maka keputusan investasi tidak mempengaruhi nilai perusahaan.

4. Pengaruh Corporate Social Responsibility terhadap Ni1ai Perusahaan

Memiliki signifikansi $0.0055<0.05$ dan koefisien -6.606304 dan $t_{\text {hitung }}>t_{\text {tabel }}$ yaitu $3.108317>2.05183$, sehingga menerima $\mathrm{H}_{0}$ dan meno1 ak $\mathrm{H}_{\mathrm{a}}$, maka Corporate Social Responsibility mempengaruhi nilai perusahaan signifikan negatif.

\section{Uji Koefisien Determinasi $\left(\mathbf{R}^{2}\right)$}

Tabel 8. Hasil Uji Koefisien Determinasi

\begin{tabular}{lrll}
\hline \hline R-squared & 0.888537 & Mean dependent var & 1.599813 \\
Adjusted R-squared & 0.827232 & S.D. dependent var & 0.769634 \\
S.E. of regression & 0.319901 & Akaike info criterion & 0.838386 \\
Sum squared resid & 2.046732 & Schwarz criterion & 1.388037 \\
Log likelihood & -1.414170 & Hannan-Quinn criter. & 1.020579 \\
F-statistic & 14.49379 & Durbin-Watson stat & 2.105108 \\
Prob(F-statistic) & 0.000000 & & \\
\hline \hline
\end{tabular}

Sumber: data diolah dari E-views

Dari tabel 8, dapat dilihat nilai Adjusted R-squared ada1ah sebesar 0.827232 atau $82.72 \%$, menandakan jika variabe1 independen yaitu Profitabilitas, Kebijakan Hutang, Keputusan Investasi, serta Corporate Social Responsibility dapat menerangkan atau menjelaskan variabe1 dependen yaitu Nilai Perusahaan sebesar $82.72 \%$, sisanya $17.28 \%$ terpengaruh dari variabe1 1ain yang tidak ada pada penelitian ini.

\section{Pembahasan \\ Pengaruh Profitabilitas terhadap Ni1ai Perusahaan}

Menurut signalling theory, profitabilitas memberikan sebuah tanda positif mengenai pertumbuhan perusahaan di masa depan kemudian akan berdampak pada meningkatnya harga saham yang menjadi indikator nilai perusahaan. Tingginya ROE menandakan kinerja perusahaan baik dalam mengelola modal para pemiliknya untuk menghasilkan keuntungan, sehingga menarik minat investor dalam melakukan investasi, sesuai dengan penelitian Pertiwi 
et a1 (2016), Ayu \& Suarjaya (2017), serta Mainul Q et a1. (2018) dimana profitabilitas memengaruhi nilai perusahaan signifikan positif.

Namun, pada penelitian ini didapatkan hasil bahwa tinggi rendahnya profitabilitas perusahaan selama periode penelitian tidak berpengaruh pada nilai perusahaan. Berdasarkan data pada sektor pertanian selalu mengalami penurunan tingkat profitabilitas tiap tahunnya, menandakan bahwa rendahnya kemampuan perusahaan dalam memperoleh laba. Namun terdapat beberapa perusahaan mengalami nilai perusahaan yang berfluktuatif. Hal tersebut dapat diartikan bahwa turunnya tingkat profitabilitas belum tentu menurunkan nilai perusahaan secara konsisten, melainkan ada faktor lain yang lebih mempengaruhi minat investor misalnya seperti pemberitaan terkini terkait suatu perusahaan yang dianggap menjanjikan. Dimana menurut Gherghina \& Vintila (2016, hlm.25) saat ini investor tidak hanya fokus terhadap keuntungan yang dihasilkan perusahaan, namun cenderung memperhatikan kegiatan sosial perusahaan yang berdampak untuk memberikan manfaat jangka panjang terhadap perusahaan. Ditarik kesimpulan jika tingkat profitabilitas rendah tidak selalu menunjukkan bahwa perusahaan memiliki nilai perusahaan rendah pula. Hasil penelitian ini sesuai dengan Sugiastuti et a1. (2018), Wahyuni \& Santoso (2019), serta Nuswandari et al (2019) yang mendapatkan hasil profitabilitas tidak memiliki pengaurh pada nilai perusahaan.

\section{Pengaruh Kebijakan Hutang terhadap Ni1ai Perusahaan}

Hasi1 pene1itian terdahulu oleh Aggarwal \& Padhan (2017), dan Hirdinis (2019), menunjukkan jika kebijakan hutang memengaruhi nilai perusahaan negatif, ketika perusahaan memiliki hutang tinggi maka diikuti dengan risiko yang tinggi pula, dimana risiko tersebut di antaranya kemungkinan laba yang diterima oleh para investor akan menjadi sedikit ketika perusahaan mempunyai kewajiban akan hutang, ditambah lagi jika perusahaan tidak punya alokasi dana khusus untuk membayar hutang tersebut, sehingga bukan tidak mungkin untuk memangkas laba yang dibagikan kepada para investor yang dapat berakibat penurunan pada nilai perusahaan. Selain itu, ketika perusahaan sudah benar-benar tidak mampu untuk membayar kewajiban yang dimilikinya, maka akan mengakibatkan hal yang sangat fatal yaitu kebangkrutan.

Berbeda dengan hasil penelitian di atas, penelitian ini memperoleh hasi1 dimana tidak adanya pengaruh kebijakan hutang pada nilai perusahaan. Berdasarkan data pada sektor pertanian, kebijakan hutang dari tahun ke tahun berfluktuatif namun nilai perusahaan secara konsisten mengalami penurunan, sehingga kenaikan atau penurunan hutang tidak mempengaruhi keputusan investor dalam berinvestasi. Selain itu, sebagaimana dijelaskan sebelumnya, menurut Aggarwal \& Padhan (2017), dan Hirdinis (2019) perusahaan dengan hutang tinggi akan berakibat pada penurunan keuntungan yang diberikan kepada investor sehingga akan menurunkan persepsi baik investor terhadap perusahaan yang akan mengakibatkan penurunan nilai perusahaan. Namun, di sisi lain perusahaan juga meyakini para investornya bahwa tingkat hutang yang tinggi jika dikelola dengan baik dapat berdampak pada keuntungan jangka panjang yang akan diberikan perusahaan kepada para investor (Isabella dan Satia, 2017, hlm. 144). Dengan adanya perbedaan cara pandang investor dalam menyikapi tingkat hutang yang perusahaan miliki, mengakibatkan kebijakan hutang tidak dapat memprediksi nilai perusahaan. Sehingga dapat disimpulkan baik saat perusahaan memanfaatkan hutang yang lebih besar maupun hutang yang lebih kecil maka tidak akan memliki pengaruh kepada nilai perusahaannya. Dimana hasil penelitian ini mendukung penelitian yang dilakukan oleh Pertiwi et a1 (2016), Sugiastuti et a1 (2018), serta Febriana et al (2020), yaitu kebijakan hutang berpengaruh terhadap nilai perusahaan secara tidak signifikan negatif. 


\section{Pengaruh Keputusan Investasi terhadap Ni1ai Perusahaan}

Saat perusahaan mempunyai tingkat investasi yang besar, menandakan adanya peluang da1am mendapat keuntungan yang sama besarnya di masa depan, dimana sesuai den gan signalling theory menyebutkan jika tingkat investasi tinggi yang perusahaan lakukan akan menjadi sinyal pertumbuhan perusahaan di masa depan, sehingga investor tertarik membeli saham serta mengakibatkan meningkatnya nilai perusahaan. Sebagaimana penelitian Pertiwi et a1 (2016) dan Purnama (2016) yang mendapat hasil bahwa keputusan investasi berpengaruh signifikan positif terhadap nilai perusahaan. Namun, berbeda dengan hasil pene1itian ini dimana tidak adanya pengaruh keputusan investasi pada nilai perusahaan.

Berdasarkan data sektor pertanian yang berfluktuatif pada keputusan investasi namun secara konsisten mengalami penurunan pada nilai perusahaan, sehingga dapat terlihat bahwa kenaikan pada investasi yang dilakukan perusahaan tidak menjamin terjadinya kenaikan pula pada nilai perusahaan, hal tersebut dapat diakibatkan oleh ketakutan para investor terhadap kemungkinan risiko yang akan terjadi ketika perusahaan melakukan tindakan investasi. Penyebab keputusan investasi tidak mempengaruhi nilai perusahaan lainnya menurut Dewi \& Wirasedana (2018, hlm.821) karena di masa yang akan datang adanya unsur ketidakpastian, di antaranya dapat berupa perubahan teknologi, kondisi sosial ekonomi dan kebijakan pemerintah. Sehingga dapat disimpulkan bahwa investor tidak akan mempertimbangkan keputusan investasi ketika menilai suatu perusahaan karena adanya ketidakpastian. Hasi1 pene1itian ini sejal an pene1itian Tumiwa et a1 (2017) serta Dewi \& Wirasedana (2018) dimana keputusan investasi berpengaruh tidak signifikan dan negatif terhadap nilai perusahaan.

\section{Pengaruh Corporate Social Responsibility terhadap Nilai Perusahaan}

Didapatkan hasil bahwa ingkat penerapan CSR mempengaruhi nilai perusahaan secara negatif, artinya semakin banyak pengungkapan CSR maka mengakibatkan turunnya nilai perusahaan. CSR merupakan wujud nyata akan bentuk tanggung jawab perusahaan kepada stakeholder, sesuai dengan stakeholder theory dimana ada hubungan yang erat antara perusahaan dengan para pemangku kepentingan. Sehingga perusahaan melakukan tindakan CSR bertujuan untuk mendapatkan kepercayaan dari para investor sehingga memberi keuntungan bagi perusahaan itu sendiri (Susila \& Prena, 2019, hlm.82). Namun menurut Vira \& Wirakusuma (2019, hlm. 1318) perusahaan menganggap CSR sebagai suatu hal yang membebankan ketika perusahaan harus mengeluarkan biaya-biaya tambahan sehingga dapat menempatkan perusahaan dalam kondisi keuangan yang sulit dan akan berakibat pada penurunan nilai perusahaan. Menurut Sabatini \& Sudana (2019, hlm. 65) dari sisi investor, tindakan CSR yang diterapkan tanpa adanya pengawasan yang baik akan menimbulkan keraguan terkait adanya penyimpangan dalam pelaksanan program CSR itu sendiri. Sehingga ketika perusahaan menerapkan program CSR, justru malah membuat investor ragu akan kinerja perusahaan tersebut dalam praktek pelaksanaannya, kemudian mengakibatkan kurangnya rasa percaya investor kepada perusahaan yang menyebabkan turunnya nilai perusahaan.

Hasil penelitian ini mendukung konsep triple bottom line yaitu evaluasi kinerja suatu perusahaan dilakukan melalui kombinasi aspek pengungkapan ekonomi, lingkungan, dan sosial. Beberapa penelitian menunjukkan bahwa pelaporan informasi ekonomi, sosial, dan lingkungan menghasilkan keunggulan dalam hal keuangan, jaminan, pemasaran, pemenuhan regulasi, dan lainnya yang merupakan tantangan dalam ekonomi global. Perusahaan harus menerapkan asas pembangunan yang seimbang melalui pengungkapan penggabungan tiga aspek tersebut dalam sebuah laporan yang dinamakan laporan keberlanjutan. Laporan keberlanjutan juga dikenal sebagai laporan Triple Bottom Line (TBL) atau Triple P (People, 
Planet dan Profit). Sehingga penelitian ini sejalan dengan penelitian yang dilakukan oleh Sabatini \& Sudana (2019) serta Vira \& Wirakusuma (2019) yang mendapat hasil bahwa CSR mempengaruhi nilai perusahaan secara signifikan negatif. Namun, tidak sejalan dengan penelitian yang dilakukan oleh Wahyuni \& Santoso (2019) dimana CSR tidak mempengaruhi nilai perusahaan.

\section{Kesimpu1an}

Berdasarkan hasil hipotesis mela1ui analisis regresi data pane1 dan pembahasan yang te1ah diuraikan, sehingga mendapat kesimpulan sebagai berikut:

Hasi1 pene1itian te1ah membuktikan bahwa variabe1 Profitabilitas yang diukur dengan Return On Equity (ROE) tidak mempengaruhi Ni1ai Perusahaan yang diukur dengan Price Book Value (PBV), sehingga hipotesis pene1itian tidak terbukti. Selanjutnya variabe1 Kebijakan Hutang yang diukur dengan Debt Equity Ratio (DER) tidak mempengaruhi Ni1ai Perusahaan yang diukur dengan Price Book Value (PBV), sehingga hipotesis penelitian tidak terbukti. Lalu, pada variabe1 Keputusan Investasi yang diukur dengan Price Earning Ratio (PER) tidak mempengaruhi Nilai Perusahaan yang diukur dengan Price Book Value (PBV), sehingga hipotesis penelitian tidak terbukti. Terakhir, pada variabe1 Corporate Social Responsibility yang diukur dengan Corporate Social Responsibility Disclosure Index (CSRDI) mempengaruhi secara negatif dan signifikan Nilai Perusahaan yang diukur dengan Price Book Value (PBV), sehingga hipotesis penelitian terbukti.

Maka saran yang dapat diberikan yaitu secara teoritis untuk pene1iti selanjutnya, alangkah lebih baik menggunakan variabel lain yang diduga mempengaruhi nilai perusahaan, selain itu dengan menggunakan perusahaan pada sektor lain sebagai sampelnya atau dalam periode waktu berbeda sehingga mungkin dapat memperoleh hasi1 1ebih baik da1am memprediksi nilai perusahaan. Secara praktis untuk manajemen perusahaan, diharapkan mampu menjalankan kegiatan operasional perusahaan secara profesional, selalu mengawasi serta melakukan evaluasi secara berkala terhadap kinerja perusahaan untuk terus mampu menaikkan nilai perusahaan. Untuk para investor diharapkan mampu melakukan pertimbangan pengambilan keputusan da1am berinvestasi pada perusahaan dengan melihat kinerja keuangan dan non-keuangan perusahaan.

\section{Daftar Pustaka}

Acep, S., Jaja, R.S., Djaja, S., Muhammad, R. (2019). Analysis Of The Benefits Of Corporate Social Responsibility Through The Triple Bottom Line Approach At Pt. Tirta Investama Indonesia. RJOAS: Russian Journal of Agricultural and Socio-Economic Sciences, 7(91), 212-220.

Aggarwal, D., \& Padhan, P. C. (2017). Impact of Capital Structure on Firm Value: Evidence from Indian Hospitality Industry. Theoretical Economics Letters, 07(04), 982-1000.

Ajija, S. R., Sari, D.W., Setianto, R.H., \& Primanti, M.R. (2011). Cara Cerdas Menguasai Eviews, Jakarta: Salemba Empat.

Akisik, O., \& Gal, G. (2017). The Impact Of Corporate Social Responsibility And Internal Controls On Stakeholders' View Of The Firm And Financial Performance. Sustainability Accounting, Management and Policy Journal, 8(3), 1-53.

Cahyono, H. S., \& Sulistyawati, A. I. (2016). Keputusan Investasi, Keputusan Pendanaan Dan Kebijakan Dividen Sebagai Determinan Nilai Perusahaan. Jurnal Akuntansi, 12(2), 3953. 
Dewi, L. P. K., \& Wirasedana, I. W. P. (2018). Pengaruh Keputusan Investasi, Keputusan Pendanaan, Kebijakan Dividen dan Tingkat Inflasi Terhadap Nilai Perusahaan. E-Journal Akuntansi Universitas Udayana, 23(2), 813-841.

Detik Finance. (2019). PDB Pertanian 2018 Tumbuh 3,7\%, Kementan: Melebihi Target. Diakses dari https://finance.detik.com/berita-ekonomi-bisnis/d-4545360/pdb-pertanian2018-tumbuh-37-kementan-melebihi-target pada tanggal 25 Mei 2020.

Fajaria, A. Z. (2018). The Effect of Profitability, Liquidity, Leverage and Firm Growth of Firm Value with its Dividend Policy as a Moderating Variable. International Journal of Managerial Studies and Research, 6(10), 55-69.

Fuad, M et.al. (2006). Pengantar bisnis. Jakarta: Gramedia Pustaka Utama

Gherghina, S. C., \& Vintila, G. (2016). Exploring The Impact Of Corporate Social Responsibility Policies On Firm Value: The Case Of Listed Companies In Romania. Economics and Sociology, 9(1), 23-42.

Hammer, J. \& Pivo, G. (2017). The Triple Bottom Line and Sustainable Economic Development Theory and Practice. Economic Development Quarterly, 31(1), 25-36.

Hirdinis, M. (2019). Capital Structure And Firm Size On Firm Value Moderated By Profitability. International Journal of Economics and Business Administration, 7(1), 174191.

Mainul Q., F. T., Sulistiyo, A. B., \& Roziq, A. (2018). Influence Policy Liabilities, Size, Growth Corporate and Profitability and Value of the Company in the Agricultural Sector in Indonesia. Research Journal of Finance and Accounting, 9(2), 54-61.

Mariani, D., \& Suryani. (2018). Pengaruh Kinerja Keuangan Terhadap Nilai Perusahaan Dengan Kinerja Sosial Dan Kinerja Lingkungan Sebagai Variabel Moderator (Studi Empiris Pada Perusahaan Pertambangan dan Manufaktur yang Terdaftar di Bursa Efek Indonesia Tahun 2011 - 2015). Jurnal Akuntansi Dan Keuangan, 7(1), 59-78.

Nabighah, D. S. (2018). The Influence Of Corporate Social Responsibility (Csr), Profitability, And Firm Size On Firm Value. Jurnal Ilmiah Mahasiswa FEB Universitas Brawijaya, $8(2), 1-16$.

Nisasmara, P. W., \& Musdholifah, M. (2016). Cash Holding, Good Corporate Governance and Firm Value. Jurnal Dinamika Manajemen, 7(2), 117-128.

Nuswandari, C., Sunarto, S., Jannah, A., \& Ikromudin, I. (2019). Corporate Social Responsibility Moderated the Effect of Liquidity and Profitability on the Firm Value. Proceedings of the International Conference on Banking, Accounting, Management, and Economics (ICOBAME 2018), 86(ICOMABE 2018), 87-90.

Ogachi, D., \& Zoltan, Z. (2020). Corporate Social Responsibility and Firm Value Protection. International Journal of Financial Studies, 8(4), 72.

Pertiwi, P. J., Tommy, P., \& Tumiwa, J. R. (2016). Pengaruh Kebijakan Hutang, Keputusan Investasi dan Profitabilitas Terhadap Nilai Perusahaan Food And Beverages yang Terdaftar di Bursa Efek Indonesia. In Jurnal EMBA: Riset Ekonomi, Manajemen, Bisnis dan Akuntansi, 4(1), 1369-1380.

Putra, A.A N.D, \& Lestari, P.V. (2016). Effect of Dividend Policy, Liquidity, Profitability and Company Size on Company Values. E-journal of Management of Unud, 5(7), 4044-4070.

Rizqia, D.A., Aisjah, S., \& Sumiati. (2013). Effect of Managerial Ownership, Financial Leverage, Profitability, Firm Size, and Investment Opportunity on Dividend Policy and Firm Value. Research Journal of Finance and Accounting, 4(11), 120-130.

Sabatini, K., \& Sudana, I. P. (2019). Pengaruh Pengungkapan Corporate Social Responsibility pada Nilai Perusahaan dengan Manajemen Laba sebagai Variabel Moderasi. Jurnal Ilmiah Akuntansi dan Bisnis, 14(1), 56-69. 
Setiono, D. B., Susetyo, B., \& Mubarok, A. (2017). Pengaruh Profitabilitas, Keputusan Investasi, Kebijakan Deviden dan Kebijkan Hutang Terhadap Nilai Perusahaan (Studi Empiris Pada Perusahaan Manufaktur Sektor Industri Barang Konsumsi Yang Terdaftar di Bursa Efek Indonesia Periode 2011-2015). PERMANA, 8(2), 32-50.

Sondakh, R. (2019). The Effect of Dividend Policy, Liquidity, Profitability and Firm Size on Firm Value in Financial Service Sector Industries Listed in Indonesia Stock Exchange 2015-2018 Period. Accountability, 8(2), 91.

Sugiastuti, R., Dzulkirom, M., \& Rahayu, S. (2018). Effect Of Profitability, Leverage Toward Dividend Policy And Firm Value. Russian Journal of Agricultural and Socio-Economic Sciences, 8(80), 88-96.

Sugiyono. (2017). Metode Penelitian Kualitatif. Untuk Penelitian yang Bersifat: Eksploratif, Enterpretif, Interaktif, dan Konstruktif, Bandung: Alfabeta.

Susila, I. M. P., \& Prena, G. Das. (2019). Pengaruh Keputusan Pendanaan, Kebijakan Deviden, Profitabilitas Dan Corporate Social Responsibility Terhadap Nilai Perusahaan. Jurnal Akuntansi : Kajian Ilmiah Akuntansi (JAK), 6(1), 80-87.

Tahu, G. P., \& Susilo, D. D. B. (2017). Effect of Liquidity, Leverage and Profitability to The Firm Value (Dividend Policy as Moderating Variable) in Manufacturing Company of Indonesia Stock Exchange. Research Journal of Finance and Accounting, 8(18), 89-98.

Vira, A.N., \& Wirakusuma, A.N. (2019). Pengaruh Pengungkapan Corporate Social Responsibility Pada Nilai Perusahaan Dengan Good Corporate Governance Sebagai Pemoderasi. E-Jurnal Akuntansi Universitas Udayana, 26(2), 1299-1326.

Wahyuni, I., \& Santoso, B. H. (2019). Pengaruh Pengungkapan CSR, Profitabilitas Dan Ukuran Perusahaan Terhadap Nilai Perusahaan Sektor Pertanian Di BEI. Jurnal Ilmu Dan Riset Manajemen, 8(3), 1-16.

Wiyono, G., \& Kusuma, H. (2017). Manajemen Keuangan Lanjutan Berbasis Corporate Value Creation. Yogyakarta: UPP STIM YKPN.

Zuhroh, I. (2019). The Effects of Liquidity, Firm Size, and Profitability on the Firm Value with Mediating Leverage. International Conference on Islamic Economics, Business, and Philanthropy (ICIEBP), 3(13), 203-230. 